Crop Breeding and Applied Biotechnology 12: 261-268, 2012

Brazilian Society of Plant Breeding. Printed in Brazil

\title{
ARTICLE
}

\section{Phenotypic and genetic characterization of partial resistance to crown rust in Avena sativa $\mathrm{L}$.}

Felipe Zambonato ${ }^{1}$, Luiz Carlos Federizzi ${ }^{1 *}$, Marcelo Teixeira Pacheco ${ }^{1}$, Marcio Pais de Arruda ${ }^{1}$ and Jose Antonio Martinelli ${ }^{1}$

Received 23 May 2011

Accepted 17 September 2012

\begin{abstract}
Crown rust is a major oat disease. Partial resistance is a promising option for disease control for being potentially more durable than complete resistance. The objective of this study was to investigate the inheritance of partial resistance to crown rust in oat populations that were derived from a cross between cultivar URS 21 (partially resistant) and URS 22 (susceptible). In 2010, the six basic generations $\left(P_{1}, P_{2}, F_{1}, F_{2}, B C_{1}\right.$, and $\left.B C_{2}\right)$ were sown in the field, and resistance to crown rust was assessed using the area under the disease progress curve, normalized and corrected for each individual plant. The inheritance of the trait partial resistance was oligogenic, indicating the presence of genes with both major and minor phenotypic effects. Additive and dominance effects were important to determine the partial resistance and the heritability estimates were high, indicating the possibility of selection for resistance in early generations.
\end{abstract}

Key words: Puccinia coronata avenae, oat, inheritance, adult plant resistance

\section{INTRODUCTION}

White oat (Avena sativa L.) is grown in Brazil as a winter cereal and is mainly cultivated in the southern region of Brazil. With an estimated production of 353,000 t harvested in 2011 (Conab 2012), Brazil is currently producing all oat grain needed for the industry. Crown rust, which is caused by Puccinia coronata f. sp. P. avenae Syd \& Syd, is a major oat disease, occurring yearly in all oat-producing regions. Yield losses caused by the disease can reach 50\% (Martinelli et al. 1994). In addition, crown rust can reduce the grain quality, which negatively affects the industrialization and commercialization of oat grain (Doehlert et al. 2001). In tropical and subtropical zones, as in the case of the oatproducing regions in Brazil, the high relative humidity and environment temperature during the growing season favor the development of oat crown rust. In these environments, pathogen populations are highly complex and specialized, with great genetic variability for virulence. For example, Leonard and Martinelli (2005) found 44 different pathogen races in 58 isolates collected in southern Brazil. Subsequently, Vieira et al. (2007) identified 30 races in 46 isolates collected in Rio Grande do Sul alone, demonstrating the high complexity of the pathogen population.
Traditionally, genes that confer complete resistance to crown rust have been studied and used in many oat breeding programs (Cruz et al. 2001, Vieira et al. 2006). Currently, 97 genes are known that confer resistance to specific races of Puccinia coronata f.sp.avenae (Chaves et al. 2008), some of which show potential for use in breeding programs, such as Pc50, Pc91 (Park 1999), Pc94 (Van Niekerk et al. 2001) and Pc68 (Van Niekerk et al. 2001, Leonard and Martinelli, 2005). With respect to the predominant oat rust races that are found in Brazil, the most promising resistance gene is Pc68, due to the low incidence of virulent pathotypes that have been found to affect it (Leonard and Martinelli 2005). However, Graichen et al. (2010) reported that the resistance that is provided by Pc 68 has been overcome in Brazil. Unfortunately, the effectiveness of genes that provide specific resistance to $P$. coronata f.sp. avenaeis is overcome so quickly that it is almost impossible to be maintained by the release of new oat cultivars, particularly in southern Brazil.

In this context, partial resistance represents a promising option because this resistance is non-specific to the race, potentially making it a more long-term solution. The trait is usually conferred by genes of minor effect on the phenotype. This resistance is incomplete and can,

\footnotetext{
${ }^{1}$ Federal University of Rio Grande do Sul (UFRGS), Department of Crop Science, Agronomy School, Av. Bento Gonçalves, 7712, 91501-970, Porto Alegre, RS, Brazil. *E-mail: federizi@ufrgs.br
} 
despite the susceptibility reaction in the host, reduce the disease development rate (Parlevliet 1985). The reduction in the disease development occurs by the modification of different resistance components such as longer latency period, lower infection efficiency, smaller pustule size, and reduction in spore production (Wahl et al. 1980, Chaves et al. 2004a).

Partial resistance to crown rust in oat was identified in genotypes of several breeding programs, e.g., line MN 8481801-1 (Portyanko et al. 2005) and the UFRGS lines (Chaves et al. 2004b). Some of these lines were studied for inheritance and identification of QTL (Quantitative Trait Loci) associated with partial resistance to crown rust (Barbosa et al. 2006, Wesp et al. 2008). The oat cultivar URS 21 has been grown on a large scale for 11 years and still retains partial resistance to crown rust. However, the genetic basis of partial resistance in this cultivar had not been investigated. The objective of this study was to identify the inheritance of partial resistance to crown rust in populations derived from URS 21 .

\section{MATERIAL AND METHODS}

\section{Plant material}

Plants of the generations $\mathrm{F}_{1}, \mathrm{~F}_{2}, \mathrm{BC}_{1}$, and $\mathrm{BC}_{2}$ of a cross between cultivar URS 21 (P1- partially resistant) and URS 22 $\left(\mathrm{P}_{2}\right.$ - susceptible) were used in this study. The cultivars URS 21 and URS 22 were selected because they are standards of partial resistance and susceptibility to crown rust, respectively. Generation $\mathrm{F}_{1}$, which was derived from the cross between the parental genotypes, was crossed with both parents to establish generations $\mathrm{BC}_{1}$ and $\mathrm{BC}_{2}$. Generation $\mathrm{F}_{2}$ was obtained from the self-fertilization of $\mathrm{F}_{1}$. The number of plants that were assessed for each generation were 79, 70, 78, 290, 66 and 52 for $\mathrm{P}_{1}, \mathrm{P}_{2}, \mathrm{~F}_{1}, \mathrm{~F}_{2}, \mathrm{BC}_{1}$ and $\mathrm{BC}_{2}$, respectively.

The experiment was conducted at the Agronomic Experimental Station of the Federal University of Rio Grande do Sul (EEA/UFRGS) in Eldorado do Sul-RS (30 $05^{\circ} \mathrm{S}$ and $\left.51^{\circ} 40^{\prime} \mathrm{W}\right)$. In 2010 , the six base generations ( $\mathrm{P} 1, \mathrm{P}_{2}, \mathrm{~F}_{1}, \mathrm{~F}_{2}$, $\mathrm{BC}_{1}$ and $\mathrm{BC} 2$ ) were sown in the field in 3-m rows, plants spaced $0.30 \mathrm{~m}$ and rows $0.20 \mathrm{~m}$ apart. The number of rows varied according to the number of seeds per generation. To increase the dose of inoculum and standardize the disease distribution during the experiment, lines of the susceptible cultivar URS 22 were sown every three lines. The experiment was conducted under normal field conditions; thus, natural inoculation was utilized by Puccinia coronata f.sp. avenae urediniospores from races that were predominant in southern Brazil.
Crown rust severity was estimated visually as the percentage of leaf area that was covered by disease pustules relative to the total leaf area of the plant. These evaluations were made individually for each plant in all generations. Eight sequential readings were performed (September 17 and 28, October 5, 12, 18 and 26and November 1 and 8) following the appearance of the first visible pustules until the beginning of leaf senescence. The area under the disease progress curve (AUDPC) was estimated by the trapezoidal integration of the curve for each individual plant from the six basic generations. The AUDPC values were normalized and corrected (AUDPCnc) by dividing the values by the number of days until the final severity reading for each genotype and multiplying the resulting values by the number of days until the final severity evaluation of the experiment, according to Graichen et al. (2010), as shown below:

$$
\text { AUDPCnc }=\left\{\left\{\Sigma\left[\left(\mathrm{y}_{\mathrm{i}+1}+\mathrm{y}_{\mathrm{i}}\right) \times 0,5\right] *\left[\mathrm{t}_{\mathrm{i}+1}-\mathrm{t}_{\mathrm{i}}\right]\right\} / \mathrm{n}\right\} * \mathrm{c} ;
$$

where:

$\mathrm{y}_{\mathrm{i}}=$ percentage of leaf area affected by crown rust (severity at the $\mathrm{i}^{\text {-th }}$ observation);

$\mathrm{t}_{\mathrm{i}}=$ time (in days) after sowing at the $\mathrm{i}^{- \text {th }}$ observation;

$\mathrm{n}=$ number of days between the disease onset and the last disease assessment;

$\mathrm{c}=$ longest period epidemic duration among the plants evaluated;

Frequency histograms were constructed for each generation and plants from generations $\mathrm{F}_{1}, \mathrm{~F}_{2}, \mathrm{BC}_{1}$ and $\mathrm{BC}_{2}$ were classified as resistant, intermediate or susceptible based on the AUDPCnc values of the parent plants $\left(\mathrm{P}_{1}\right.$ and $\mathrm{P}_{2}$ ). Individual plants with AUDPCnc values that were less than or equal to the greatest value that was determined for the resistant parent were classified as resistant. Plants were classified as susceptible if they had AUDPCnc values that were equal to or greater than the lowest value that was determined for the susceptible parent. The other plants were classified as intermediate.

Based on the distribution frequency of the plants of each generation, a genetic model was designed to explain the segregation of partial resistance to crown rust in the cross used. Hypotheses regarding the parental genotypes were formulated and tested against the frequency distribution observed in the different generations studied. The adequacy of this theoretical model was tested by the chi-square test $\left(\chi^{2}\right)$ at $5 \%$ probability.

A generation means analysis was performed using the method of weighted least squares, according to Mather and Jinks (1982). The mean components for each generation were determined by the following equations:

$\mathrm{P}_{1}=\mathrm{m}+\mathrm{a}, \mathrm{P}_{2}=\mathrm{m}-\mathrm{a}, \mathrm{F}_{1}=\mathrm{m}+\mathrm{d}, \mathrm{F}_{2}=\mathrm{m}+1 / 2 \mathrm{~d}$, 
$\mathrm{BC}_{1}=\mathrm{m}+1 / 2 \mathrm{a}+1 / 2 \mathrm{~d}$ and $\mathrm{BC}_{2}=\mathrm{m}-1 / 2 \mathrm{a}+1 / 2 \mathrm{~d}$,

where :

$\mathrm{m}=$ mean component (mean value of the parents), $\mathrm{a}=\mathrm{ad}-$ ditive component (deviation of the parents in relation to $m$ ), $d=$ dominance component $\left(\mathrm{F}_{1}\right.$ deviation in relation to $\left.m\right)$. The adequacy of the additive-dominant model was tested by the chi-square test $\left(\chi^{2}\right)$ at $5 \%$ probability, considering the deviations of the six base populations.

The components of genetic and environmental variance for partial resistance to crown rust were estimated based on the phenotypic variance of each generation, according to Allard (1960):

$\mathrm{V}_{\mathrm{P} 1}=\mathrm{V}_{\mathrm{E}} ; \mathrm{V}_{\mathrm{P} 2}=\mathrm{V}_{\mathrm{E}} ; \mathrm{V}_{\mathrm{F} 1}=\mathrm{V}_{\mathrm{E}} ; \mathrm{V}_{\mathrm{F} 2}=\mathrm{V}_{\mathrm{P}} ; \mathrm{V}_{\mathrm{BC} 1}=\mathrm{V}_{\mathrm{G}}+\mathrm{V}_{\mathrm{E}} ; \mathrm{V}_{\mathrm{BC} 2}=$ $\mathrm{V}_{\mathrm{G}}+\mathrm{V}_{\mathrm{E}} ; \mathrm{V}_{\mathrm{G}}=\mathrm{V}_{\mathrm{F} 2}-\left[\left(\mathrm{V}_{\mathrm{P} 1} * \mathrm{~V}_{\mathrm{P} 2} * \mathrm{~V}_{\mathrm{F} 1}\right)^{1 / 3}\right] ; \mathrm{V}_{\mathrm{E}}=\left(\mathrm{V}_{\mathrm{P} 1} * \mathrm{~V}_{\mathrm{P} 2} * \mathrm{~V}_{\mathrm{F} 1}\right)^{1 / 3}$; $\mathrm{V}_{\mathrm{A}}=2 . \mathrm{V}_{\mathrm{F} 2}-\left(\mathrm{V}_{\mathrm{BC} 1}+\mathrm{V}_{\mathrm{BC} 2}\right) ; \mathrm{h}^{2} \mathrm{a}=\mathrm{V}_{\mathrm{G}} / \mathrm{V}_{\mathrm{P}} ; \mathrm{h}^{2} \mathrm{r}=\mathrm{V}_{\mathrm{A}} / \mathrm{V}_{\mathrm{P}}$, where: $\mathrm{V}_{\mathrm{P} 1}=$ phenotypic variance of parent $1, \mathrm{~V}_{\mathrm{P} 2}=$ phenotypic variance of parent $2, \mathrm{~V}_{\mathrm{F} 1}=$ phenotypic variance of the $\mathrm{F}_{1}$ generation, $\mathrm{V}_{\mathrm{F} 2}=$ phenotypic variance of the $\mathrm{F}_{2}$ generation, $\mathrm{V}_{\mathrm{BC} 1}=$ phenotypic variance of backcross $1, \mathrm{~V}_{\mathrm{BC} 2}=$ phenotypic variance of backcross $2, \mathrm{~V}_{\mathrm{G}}=$ estimate of genetic variance, $\mathrm{V}_{\mathrm{E}}=$ estimate of environmental variance, $\mathrm{V}_{\mathrm{A}}=$ estimate of additive genetic variance, $\mathrm{V}_{\mathrm{D}}$ = estimate of dominant genetic variance, $\mathrm{h}_{\mathrm{b}}{ }_{\mathrm{b}}=$ estimate of broad-sense heritability, $\mathrm{h}^{2}{ }_{\mathrm{n}}=$ estimate of narrow-sense heritability.

\section{RESULTS AND DISCUSSION}

Cultivar URS 21 had a slow disease progression, and the mean severity stabilized at approximately $10 \%$ during the final two assessments (Figure 1). However, the crown rust was fully developed in cultivar URS 22, which typically occurred by the fourth reading, reaching a mean severity of $73 \%$ in the final assessment. The disease progression that was observed in URS 21 was less severe than that which has been reported in the literature for other oat lineages that are partially resistant to crown rust (Chaves et al. 2004, Wesp et al. 2008). This suggests that cultivar URS 21 also has partial resistance to crown rust and that in 2010, the environmental conditions favored the development of the pathogen, given the high disease severity that was observed in URS 22.

The range of AUDPCc values for the susceptible parents was considerably greater than that observed for the parents with partial resistance, suggesting a larger variation in susceptible genotypes (Table 1). The mean AUDPCnc values for generations $\mathrm{F}_{1}$ and $\mathrm{F}_{2}$ showed deviations compared with the parental mean (507.73) and were closer to the parental mean with partial resistance (75) than to that of the susceptible parents (940). Generation $\mathrm{F}_{2}$ showed a large variation in AUDPCc values because it included plants ranging from immune to highly susceptible, suggesting the presence of a continuous distribution of crown rust resistance in this population. Generations $\mathrm{F}_{2}$ and $\mathrm{BC}_{1}$ showed asymmetrical distributions, indicating that dominance effects control this trait (Figure 2). This distribution is different from that observed for the inheritance of complete resistance in recombinant oat lines containing $P c 68$, as reported by Graichen et al. (2010), and similar to the distribution that was obtained by Portyanko et al. (2005) in a study involving the genotype MN 841801-1, which is also partially resistant to oat crown rust.

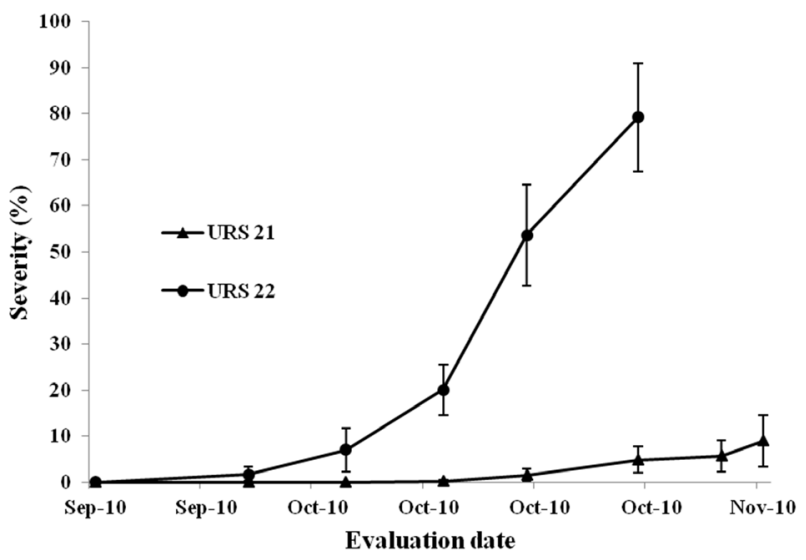

Figure 1. Mean disease progress curves of oat crown rust in the parent genotypes URS 21 (resistant) and URS 22 (susceptible) and linear regression. Bars represent \pm 1 standard deviation. Eldorado do Sul-RS, 2010.

Based on the frequency histograms of the six generations studied, genetic models were developed with two, three, four, and five loci. The model consisting of five loci best explained the segregation in $\mathrm{F}_{2}, \mathrm{BC}_{1}$ and $\mathrm{BC}_{2}$. This model consists of two major-effect loci ( $\mathrm{A}$ and $\mathrm{B}$ ) and three loci with minor effect on the phenotype (C, D and $\mathrm{E})$. One of the major-effect loci (A) confers resistance when it is recessive ("aa") and the other (B) confers resistance when dominant as "BB". The minor-effect loci are dominant for resistance ("C_", "D_" and "E_"). Thus, the proposed genotypes of the resistant and susceptible parents are "aaBBCCDDEE" and "AAbbccddee ", respectively. In the $\mathrm{F}_{1}$ generation, the effects of loci A and B were canceled, and the displacement of the average $F_{1}$ toward the resistant parent (Figure 2) is given by the action of heterozygous minor-effect loci ("Cc", "Dd" and "Ee"). Based on this model, the expected and observed genotypes in each phenotypic class are shown in Table 2. The chi-square adherence test was not significant for the three segregating generations, which shows the adequacy of the model. These data confirm the complexity of the inheritance of partial resistance to crown rust, previously 

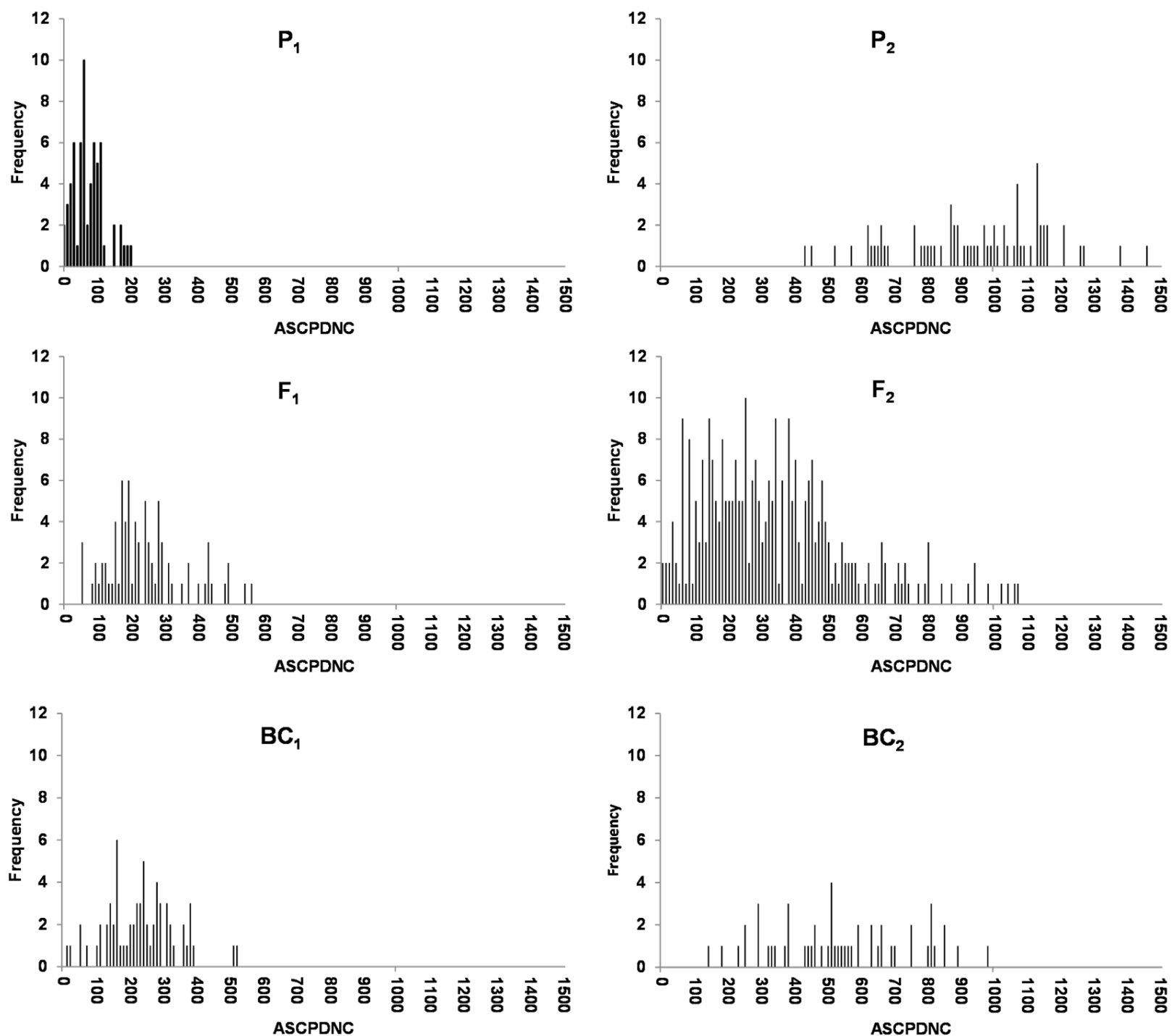

Figure 2. Frequency distribution of the AUDPCnc values of plants of six generations of the cross between URS $21\left(\mathrm{P}_{1}\right)$ and URS $22\left(\mathrm{P}_{2}\right)$.

mentioned by Portyanko et al. (2005). According to Johnson (1984) and McDonald and Linde (2002), the inheritance of partial resistance to highly specialized pathogens is often complex, particularly with pathotypes that carry multiple virulence genes, such as rusts, because they can increase the durability of the resistance, even under environmental conditions that are very favorable for pathogen dissemination, as observed for the parent URS 21 .

The components of genetic variance, environmental variance and heritability are shown in Table 3 . The genetic was higher than the environmental variance, resulting in a high estimate of broad-sense heritability $(76 \%)$. The estimated additive variance was more than double the dominance variance.
Thus, the narrow-sense heritability $\left(\mathrm{h}^{2}\right)$ was also high (91\%). The higher estimate of $\mathrm{h}^{2}$ over $\mathrm{h}_{\mathrm{b}}{ }_{\mathrm{b}}$ was probably related to an overestimation of the environmental variance $\left(\mathrm{V}_{\mathrm{E}}\right)$, especially due to the variation observed in the susceptible parent. Moreover, the additive effects are more important than dominance effects, which is very important in autogamous plants. High heritability estimates in studies on partial resistance to crown rust have been reported in other studies, e.g., of Holland and Munkvold (2001) and Barbosa-Preste et al. (2008). Although partial resistance is a genetic trait with complex inheritance (Portyanko et al. 2005), and the pathogen population in the southern Brazil has many virulence genes (Leonard and Martinelli 2005, Vieira et al. 2007), the heritability estimates in 
Phenotypic and genetic characterization of partial resistance to crown rust in Avena sativa L.

Table 1. Minimum, maximum and mean AUDPCnc values of plants of the resistant, intermediate and susceptible classes of each generation.

\begin{tabular}{|c|c|c|c|c|c|c|c|}
\hline \multirow{2}{*}{ Generation } & \multicolumn{3}{|c|}{ AUDPCnc } & \multicolumn{4}{|c|}{ Number of plants } \\
\hline & Minimum & Mean & maximum & $\operatorname{Res}^{1}$ & Inter $^{2}$ & $\mathrm{Susc}^{3}$ & Total \\
\hline P1 & 1.66 & 75.37 & 199.38 & 63 & . & . & 63 \\
\hline $\mathrm{P}_{2}$ & 433.17 & 940.09 & 1459.90 & . & . & 68 & 68 \\
\hline F1 & 45.50 & 240.00 & 558.92 & 35 & 34 & 9 & 78 \\
\hline F2 & 0.00 & 332.63 & 1072.94 & 93 & 111 & 86 & 290 \\
\hline $\mathrm{BC}_{1}$ & 10.40 & 230.18 & 517.71 & 26 & 38 & 2 & 66 \\
\hline $\mathrm{BC} 2$ & 144.86 & 536.88 & 983.77 & 2 & 13 & 37 & 52 \\
\hline
\end{tabular}

${ }^{1}$ Res $=$ resistant; ${ }^{2}$ Inter $=$ intermediate ${ }^{3}$ Susc $=$ susceptible

Table 2. Model inheritance of partial resistance to oat crown rust for generations $\mathrm{F}_{2}, \mathrm{BC}_{1}$ and $\mathrm{BC}_{2}$. Phenotypic classes, possible genotypes and chisquare $\left(\chi^{2}\right)$.

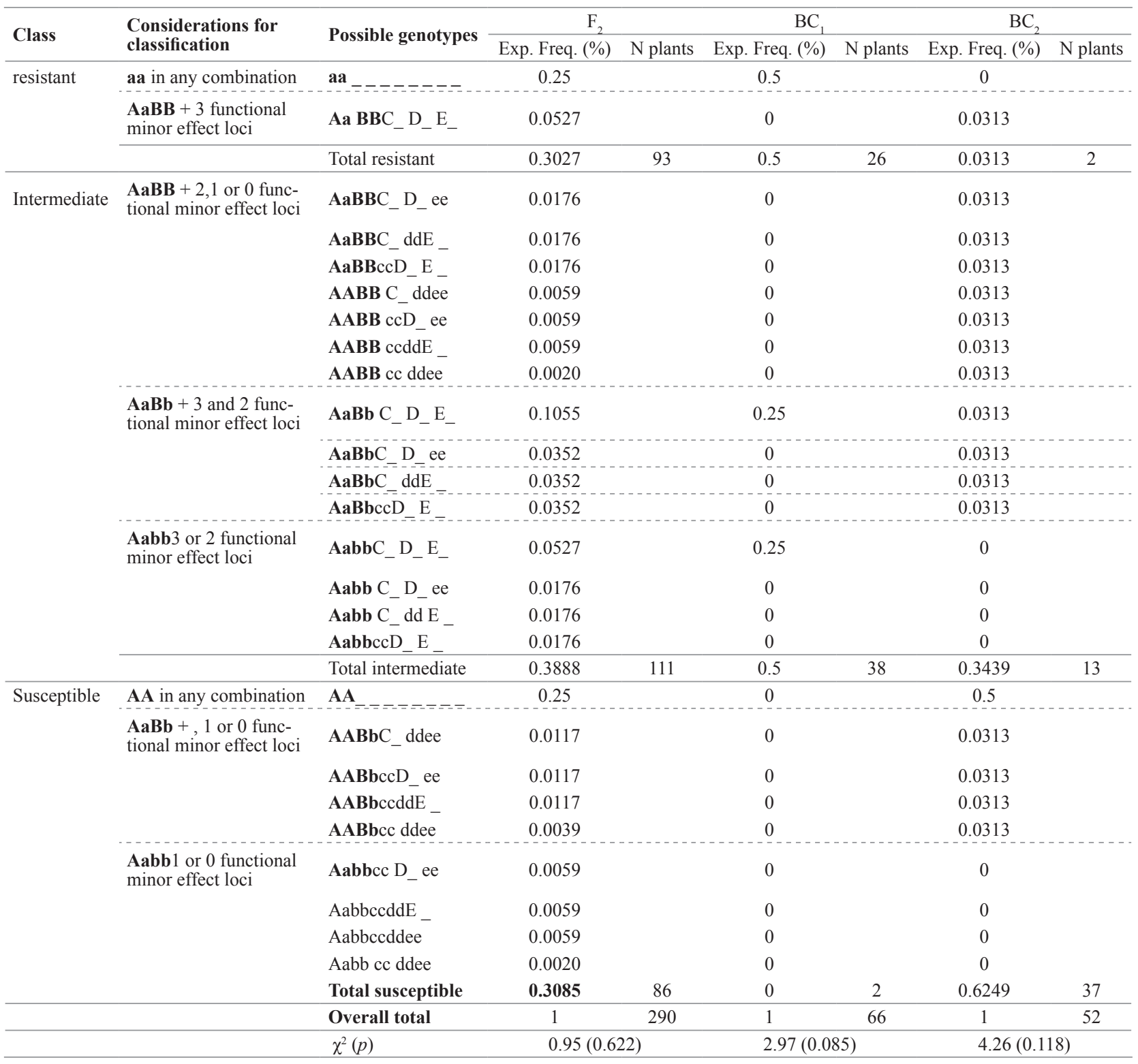


Table 3. Estimate of the phenotypic variance $\left(V_{\mathrm{P}}\right)$, environmental variance $\left(\mathrm{V}_{\mathrm{E}}\right)$, genetic variance $\left(\mathrm{V}_{\mathrm{G}}\right)$, additive variance $\left(\mathrm{V}_{\mathrm{A}}\right)$, dominance variance $\left(\mathrm{V}_{\mathrm{D}}\right)$ and broad- and narrow-sense heritabilities for AUDPCnc.

\begin{tabular}{lc}
\hline Parameter & Estimate \\
\hline Phenotypic variance $\mathrm{F}_{2}\left(\mathrm{~V}_{\mathrm{F} 2}\right)$ & 47480 \\
Environmental variance $\left(\mathrm{V}_{\mathrm{E}}\right)$ & 11321 \\
Genotypic variance $\left(\mathrm{V}_{\mathrm{G}}\right)$ & 36159 \\
Additive variance $\left(\mathrm{V}_{\mathrm{A}}\right)$ & 28507 \\
Dominance variance $\left(\mathrm{V}_{\mathrm{D}}\right)$ & 11410 \\
Broad-sense heritability $\left(\mathrm{h}_{\mathrm{b}}^{2}\right)$ & $76 \%$ \\
Narrow-sense heritability $\left(\mathrm{h}_{\mathrm{n}}^{2}\right)$ & $91 \%$ \\
\hline
\end{tabular}

this study were high allowing the identification of genotypes with partial field resistance. In the analysis of the genetic $m$, $d$ and $a$, a negative effect was observed for the additive (a) as well as the dominant component (d). The magnitude of the effect of (a) was much higher than the magnitude of the effect of (d), but both were significant and important in determining the trait (Table 4). The existence of the additive component (a) with a negative sign is due to the fact that the resistant parent URS $21\left(\mathrm{P}_{1}\right)$ had the lowest severity scores and, consequently, the lowest AUDPCc values. The goodness-of-fit test for the model resulted in a non-significant $\chi 2$ value $(p=0.9214)$ for the additive-dominant model. In other words, the parameters $m, d$ and $a$ were sufficient to explain the phenotypic variation observed in the six generations and corroborate the high heritability estimates.
The results of this study show that URS 21 is partially resistant to crown rust, with a low disease progress and reduced final severity. The average values of final severity could be even lower, since in the experiment the resistant parent was sown alongside URS 22, the susceptibility standard. The partial resistance inheritance is oligogenic, with action of major- and minor-effect loci on the phenotype. Both additive and dominance effects are important to determine the trait. Considering the high variability in virulence of Puccinia coronata f.sp. avenae populations in southern Brazil, combined with the high yield potential, the cultivar URS 21 represents a unique genotype both for breeding and with regard to oat cultivation. Summarizing, cultivar URS 21 meets the three basic requirements suggested by Johnson 1984 to obtain effective durable resistance: (1) its partial resistance was maintained a long time (since 1999), (2) in a highly pathogen-favorable environment (Southern Brazil) (3) on a relatively large area of cultivation (URS 21 is being grown on an extensive area since 2000).

\section{CONCLUSIONS}

The inheritance of partial resistance to oat crown rust in URS 21 is oligogenic. The trait control appeared to be related to two (partially dominant) major-effect loci and three (completely dominant) loci with minor effect on the phenotype. Heritability estimates were high, indicating the possibility of selection for partial resistance from the first generations.

Table 4. Estimates of mean genetic parameters ( $\mathrm{m}$ ), additivity (a) and dominance (d), standard error, and fitting error ( $\chi^{2}$ and $\left.\mathrm{P}\right)$ based on analyses of means of six oat generations evaluated for resistance to oat crown rust. Eldorado do Sul-RS, 2010.

\begin{tabular}{llccc}
\hline Cross & Estimate \pm standard error & $\mathrm{t}$ & Model & $\chi^{2}(\mathrm{df})$ \\
\hline URS 21 & $\mathrm{m}=491.41 \pm 39.77$ & $12.35^{* *}$ & & $\mathrm{P}$ \\
$\mathrm{x}$ & $\mathrm{a}=-410.56 \pm 39.66$ & $-10.35^{* *}$ & $\mathrm{Y}=\mathrm{m}+\mathrm{d}+\mathrm{a}$ & $0.4886(3)$ \\
URS 22 & $\mathrm{d}=-228.78 \pm 60.85$ & $-3.76^{*}$ & & 0.9214 \\
\hline
\end{tabular}

*: Significant at $5 \%$ probability by the $\mathrm{t}$ test; **: Significant at $1 \%$ probability by the $\mathrm{t}$ test

\section{Caracterização fenotípica e genética da resistência parcial à ferrugem da folha em Avena sativa L.}

Resumo - A ferrugem da folha é uma das principais doenças da aveia. A resistência parcial é uma opção promissora no controle da moléstia, pois é potencialmente mais durável que as resistências completas. O objetivo deste trabalho foi estudar a herança da resistência parcial à ferrugem da folha em populações derivadas do cruzamento entre a cultivar URS 21 (parcialmente resistente) e URS 22 (suscetível). Em 2010 as seis gerações básicas $\left(P_{1}, P_{2}, F_{1}, F_{2}, R C_{1}\right.$ e $\left.R C_{2}\right)$ foram semeadas no campo, e a resistência à ferrugem da folha foi avaliada através da área sobre a curva de progresso da doença normalizada e corrigida, para cada planta individual. O caráter apresentou herança oligogênica, com presença de genes de grande e pequeno efeito sobre o fenótipo. Efeitos aditivos e de dominância foram importantes na determinação do caráter e as estimativas de herdabilidade foram elevadas, indicando possibilidade de seleção em gerações precoces.

Palavras-chave: Puccinia coronata avenae, aveia branca, resistência de planta adulta, herança. 
Phenotypic and genetic characterization of partial resistance to crown rust in Avena sativa L.

\section{REFERENCES}

Allard RW (1960) Principles of plant breeding. Wiley, New York, 485p.

Barbosa-Prestes MM, Federizzi LC, Milach SCK and Martinelli JA(2008) Controle genético da resistência parcial à ferrugem da folha em aveia (Avena sativa L.). Ciência Rural 38: 308-314.

Barbosa-Prestes MM, Federizzi LC, Milach SCK, Martinelli JA and Thome GHC (2006) Molecular mapping and identification of QTL's associated to oat crown rust partial resistance. Euphytica 150: 257-269.

Chaves MS, Martinelli JA and Federizzi LC (2004) Resistência quantitativa à ferrugem da folha em genótipos de aveia branca: I - Caracterização da reação em condições de campo Fitopatologia Brasileira 29: 39-46.

Chaves MS, Martinelli JA and Federizzi LC (2004) Resistência quantitativa à ferrugem da folha em genótipos de aveia branca: II - Avaliação de Componentes de Resistência. Fitopatologia Brasileira 29: 47-55.

Chaves MS, Martinelli JA, Wesp CL and Graichen FAS (2008) The cereal rusts: an overview. Pest Technology 2: 38-55.

Cruz RP, Federizzi LC and Milach SCK (2001) Genética da resistência à ferrugem da folha em aveia. Pesquisa Agropecuária Brasileira 36: $1127-1132$.

CONAB (2012) Acompanhamento da safra brasileira de Grãos: Janeiro de 2012. Available at $<$ http//www.conab.gov.br $>$. Acessed on Feb 22, 2012.

Dohelert DC, McMullen MS and Hammond JJ (2001) Genotypic and environment effects on grain yield and quality of oat grown in North Dakota. Crop Science 41: 1066-1072.

Graichen FAS, Martinelli JA, Federizzi LC, Pacheco MT, Chaves MS and Wesp CL (2010) Inheritance of resistance to oat crown rust in recombinant inbred lines. Scientia Agricola 67: 435-440.

Holland JB and Munkvold GP (2001) Genetic relationships of crown rust resistance, grain yield, test weight and seed weight in oat. Crop Science 41: 1041-1050.

Johnson R (1984) A critical analysis of durable resistance. Annual Review of Phytopathology 22: 309-330.

Leonard KJ and Martinelli JA (2005) Virulence of Oat Crown Rust in Brazil and Uruguay. Plant Disease 89: 802-808.
McDonald B A and Linde C (2002) Pathogen population genetics, evolutionary potential, and durable resistance. Annual Review Phytopatology 40: 349-379.

Martinelli JA, Federizzi LC and Benedetti AC (1994) Redução no rendimento de grãos de aveia em função da severidade da ferrugem da folha. Summa Phytopathologica 40: 116-118.

Mather SK and Jinks JL (1982) Biometrical genetics: the study of continuous variation. London and New York, Chapman and Hall, 396p.

Park RF (1999) Pathogenic changes in Puccinia coronata (oat crown rust pathogen) with respect to recently deployed crown rust resistance cultivars in Australia. Oat Newsletter 45. Available at http://www.wheat. pw.usda.gov/ggpages/oatnewsletter/v45/. Acccessed May12, 2011.

Parlevliet JE (1985) Resistance of the nonrace-specific type. In Bushnell WR and Roelfs AP (eds.) The Cereal Rusts vol II: Diseases, distribution, epidemiology and control. Academic Press, New York, p.501-525.

Portyanco VA, Chen G, Rines HW, Phillips RL, Leonard KJ, Ochocki GE and Stuthman DD (2005) Quantitative trait loci for partial resistance to crown rust, Puccinia coronate, in cultivated oat (Avena sativa L.) Theoretical and Applied Genetics 111: 313-324.

Van Niekerk BD, Pretorius ZA and Boshoff WHP (2001) Pathogenic variability of Puccinia coronata $\mathrm{f}$.sp. avenae and Puccinia graminis f.sp. avenae on oats in South Africa. Plant Disease 85: 1085-1090.

Vieira EA, Carvalho FIF, Chaves MS, Oliveira AC, Silva JAG, Bertan I, Schmidt DAM, Ribeiro G, Finatto T and Silveira G (2006) Herança da resistência à ferrugem da folha (Puccinia coronata f.sp. avenae Fraser \& Led.) em genótipos brasileiros de aveia branca. Ciência Rural 36: 135-141.

Vieira EA, Carvalho FIF, Chaves MS, Oliveira AC, Benin G, Hartwig I, Silva JAG, Bertan I, Martins AF and Martins LF (2007) Virulence variability of Puccinia coronata $\mathrm{f}$. sp. avenae isolates collected in three counties from Rio Grande do Sul State, Brazil. Plant Disease 91: 66-70.

Wahl I, Wilcoxson RD and Rowell JB (1980) Slow rusting of wheat and stem rust detected in the glasshouse. Plant Disease 64: 54-56.

Wesp CL, Martinelli JA, Chaves MS, Graichen, FAS and Federizzi LC (2008) Herança da resistência quantitativa à ferrugem da folha em linhagens recombinantes de aveia branca. Tropical Plant Pathology 33: $138-147$. 
F Zambonato et al. 